\title{
Learning How to Use Buildings: An Exploration of the Potential of Design Interactions to Support Transition to Low-Impact Community Living
}

\section{Rachael Luck}

The Design Group, Department of Engineering and Innovation, The Open University, Walton Hall, Milton Keynes MK7 6AA, UK; E-Mail: rachael.luck@ open.ac.uk; Tel.: +44-1908-858224; Fax: +44-1908-653858

External Editor: Alice Moncaster

Received: 18 July 2014; in revised form: 28 October 2014 / Accepted: 6 November 2014 / Published: 27 November 2014

\begin{abstract}
In this paper, I study how a housing project is designed and show the architects in conversation with the residents talking about living in a community with lower impact, to reveal different conceptual understandings of building technologies and systems within the home. In this account, it can be seen that building systems and technologies become entangled with dwelling, patterns of living and maintenance scenarios on a housing estate. Shown are several ways that these design interactions can be considered pedagogic and transformative. It is proposed that similar events between architects and users are established in the design stage for other building types and for more of the UK housing stock.
\end{abstract}

Keywords: design; learning; architect; participation; housing; community; transitions; low carbon; science and technology studies; building systems

\section{Introduction}

In the influential book "How Buildings Learn", Stewart Brand [1] draws our attention to the life of buildings and to their afterlives, through retrofit and redevelopment. Since its publication, buildings are increasingly acknowledged to have a life cycle and to change, constantly. Buildings, although not mobile, can be thought of as mutable. These terms are used knowingly to acknowledge that "How Buildings Learn" looks at the through-life change and maintenance of buildings, from the building's perspective. In doing so, it gives credence to post-occupancy evaluation, facilities management and 
corporate real estate management's interests in what happens to buildings after they are built. A building is a technology that although bound to one location is open to interpretation. The origins for some of these ideas are founded in the philosophy of science and the philosophy of technology, as advanced in studies of science, technology and society, STS [2], where relationships between technology and society are examined from a constructivist perspective and interpretive flexibility is a core concept. From this perspective we understand that technology is not considered to determine human action but human action does shape technology. For example, we shape buildings in their design and re-configuration and buildings shape us in their multiple uses, including their everyday habitation. Indeed, Gieryn [3] describes a "building as the object of human agency and as an agent of its own interpretative flexibility". Given that science and technology studies continue to debate relationships between people and things (technologies in society), this article's examination of relationships between people and buildings and how we learn how to use them remains a fertile subject.

In Brand's study he builds on Frank Duffy's understanding of the layering of buildings [1] (p. 13), which distinguishes building systems (heating, lighting, ventilation, etc.), from structure and the configuration of furniture within inhabited buildings. These are important distinctions that provide a way of talking about buildings as systems, technologies and socio-technical systems more specifically [4], which, as we will see, are sometimes misunderstood. In this paper, I build on these insights but reverse Brand's perspective to question how people learn how to use buildings, or phrasing the purpose of the study more precisely, how might learning be understood as part of the experience of designing and using a building? This subject is approached with a particular interest in mind, to better understand how we might inhabit buildings with less impact on the environment. The thesis explored in this argument is that the conversations between architects and users, in the process to design a building, provide a platform for learning how to live more sustainably in communities. In particular, for the users to become more knowledgeable about technologies within buildings and mindful of how their everyday practices, habits and lifestyle impact on the environment.

To study this, the paper is organized as follows. First, by examining the renewed research interest in relationships between people and buildings. Next I introduce the study of a housing estate in London and present select episodes to show several ways that building systems were understood by the residents, and how some building technologies become entangled in narratives of estate-life and ways of living in this community. The proposition that is advanced through this research is that these design interactions are sites of learning, events when learning how to live more sustainably in this community is interwoven with the design of the dwellings. At present, however, these events are under-acknowledged for their pedagogic and transformative potential and in the design of some buildings these kinds of meetings never take place. It is the learning potential of these interactions between architects and users that this research draws attention to, especially as we transition to living with less impact on the environment in a lower carbon economy.

\section{Using Buildings}

There is renewed interest in understanding how people use buildings. This interest is in part driven by the low-carbon agenda where, through different forms of evaluation there is a known knowledge gap between what is built and our understanding of how buildings perform. There is a gulf between the 
energy performance of buildings as simulated at the design stage that differs from the energy consumed in use [5]. The occupants of buildings are seemingly doing something different within the built form from what the designers of the simulation programs assume, and different from the in-use conditions that the software algorithms model. This performance difference continues to attract research attention. There are a number of studies of living in low and zero carbon (LZC) homes that report difficulties some occupants have with building controls [6], understanding the operation of heating [7] and micro-generation technologies [8], including instances when the process of learning how to use eco-features in new homes was specifically mentioned [9].

In a persuasive argument, the Vales [10] take the sustainable futures debate further, building on the seminal views of Whole Earth [11] and the agitprop Street Farm movement [12] and emphasize that it takes more than efficient space heating and housing design to reduce our impact on the planet. When housing is constructed with ample insulation, is orientated in the right direction and is free-running (without mechanical ventilation) then its energy demand centers on the use of stuff [13,14], the technical artifacts people use within houses and not solely on the material fabric and building services of the home. Indeed, knowing how to build passive houses is no longer a technical problem [15]. After construction, it is not the housing fabric but what people do in houses, that substantively affects energy demand and the carbon emitted [16]. To reduce our impact on the environment by moderating some small habits, everyday practices and lifestyle are important, as well as technological change in the built form. Indeed, local habits and practices are now written into larger scale assessments of environmental impact: how clothes are washed and dried, close access to public transportation and sourcing electricity locally are practices that take place within the home, in the community and at a city scale, all of which are now entangled in the way housing efficiency ratings are calculated and in the assessment of a European green city. This increase in scale needs more explanation.

There is debate whether autonomy is sufficient for social transformation, that is, whether individual change, or numerous individual's actions, will make a difference. Bookchin's [17] philosophy seems to anticipate this critique. Bookchin was committed to local democratic participation and community scale production. His philosophy of technology placed emphasis on the social matrix within which technology operates, re-embedding technology in a web of communal social relations and ethics. He stressed the need for technologies to be compatible with face-to-face decisions made in assemblies, where "an authentic community is not merely a structural constellation of human beings but rather a practice of communizing". In this there is a shift in unit from an individual to the actions of a community, and this way of thinking has a history.

More than 40 years ago, it took high levels of personal commitment for the pioneers of progressive initiatives at CAT [18] and Vauban in Freiburg to live in settlements with less impact on the environment. In today's mainstreaming of many of these co-evolution ideas [19] there is an upscaling of what were once viewed as alternative lifestyles, through citizen-led initiatives in the community and intervention at a city scale [20,21]. Bookchin's ideas [17] preceded the local heat and power generation solutions and the potential for local production that are currently promoted.

Studies of the transition to a lower carbon economy routinely examine interactions across different layers within a complex system [22-25], across the units of analysis that built environment research separates into buildings, community architecture, urban design and the planning of infrastructure at a 
city scale. In this paper, I study the design of lower-impact housing and show how this entangles thinking about buildings as systems at different scales in relation to the life of a community.

\section{The Study}

Adopting a stance that questions how people learn how to use buildings, and housing in particular, might seem unusual: habitation is a human trait, what do the occupants need to learn? There are two reasons for this framing. Learning is increasingly understood as an experiential form of knowledge that is ongoing throughout life [26] in our being and dwelling [27], as people learn what they are already doing. The philosophical and theoretical ground for this view of learning can be traced through John Dewey in pragmatism, where education is viewed as a place to learn how to live and in the later philosophy of Martin Heidegger, examining dwelling and being-in-the-world [28]. These theories are applied in Meg Holden's studies of innovation and learning in a civic network, as part of Seattle's sustainable community initiative [21,29]. A commonality is the recognition of an always, ongoing understanding of a situation. A view that is empathetic with the temporal unfolding that Brand [1] sees in the life-cycle of buildings, a co-evolving socio-technical system. The second reason for this framing is because it is not only in educational settings that people "learn". Design is viewed as pedagogy [30] (p. 11). Architects learn how to engage in co-design activities with users in practice, to discuss, for example the merits of different kinds of green-roof technologies [31]. At co-design events designers characteristically become knowledgeable and can "learn" from people's lived experiences, as well as gain what might be construed as "informational" insights from a situation. A less examined aspect in the reciprocal exchange of "knowing" and "becoming" at co-design events is what people "learn" about buildings in their interactions with designers, and in the project examined in this paper specifically, the art of learning how to live in buildings more sustainably. This design challenge is not about making greener widgets but how to make communities that fit their places [17].

To examine the art of learning how to live in buildings more sustainably, the design stages for a social housing project were shadowed through the interactions that took place between a firm of architects, several housing officers and the user-residents who will live in the dwellings. These design interactions between architects and resident groups are routine for social housing projects and are mandated for some public funded projects. The extracts presented are taken from a corpus of ethnographic materials, attending all the planned meetings, workshops and events for this project over a five-month period. Audio and video recordings of these events were supplemented with field notes and materials collected on an architectural field trip the practice arranged to view housing in the Netherlands. Building on this ethnography I draw attention to select episodes when the use of building systems, technologies and the low-carbon design features proposed for these dwellings were brought into conversation and reveal several practical and conceptual (mis)understandings of technologies within the home. These episodes focus our attention on how the design of housing becomes entangled with how to live in dwellings, to engender a sense of community on this estate.

\subsection{Designing for A Way of Life in This Community}

There is a palpable sense of expectation that surrounds the design of new dwellings on a housing estate, in the potential to transform the lives of the people who will live there. Housing can act as a 
catalyst for change not only in the built, physical form but also through revitalizing the lives and outlook of people in a neighborhood. This becomes evident in the way the future inhabitants of the dwellings, the local authority housing officers and architects talk about the project examined in this paper. However, this enthusiasm is moderated by many years' experience and we begin to sense this practical realism as a Housing Offer says, "my concern is that a new tenant will go along and they'll choose all the fantastic things and then fifteen years later somebody will end up with that flat because that's how the system works and well from experience the problem is that there's no support at that point there is a lot of support to start off with but later on there isn't so it's that failsafe in between, I'm not quite sure how that's going to work".

The housing officer exhibits her astute understanding of the lifecycle of dwellings and the system of social housing, knowing that the management, maintenance and support for the tenants throughout the lifespan of the housing stock will impact on whether the transformation that this project promises will be sustainable. The architects respond with an example:

Trainee architect: Can I just give an example there?

Project architect: We went on an office trip to the southern German city of Freiburg and there's a kind of sustainable, well maybe that sounds, a sustainable community that sounds a bit strange, there's a sort of suburb of the city that has had for quite a long time a very strong sustainable eco agenda and as a result there are interesting buildings and interesting communities there

Trainee architect: Well what I think, really what I've learnt from that it is that actually it's exactly what you say, after fifteen years somebody else moves in but you're not going to be like any other community you're going to be close knit, people are going to share their knowledge and are going to welcome other people, and are going to provide that support as part of the community

The trainee architect puts into words what she learnt from her visit to Freiburg, articulating a scenario for this estate in fifteen years' time. She builds on this experience to reason that this community will be mutually supportive, "you're not going to be like any other community, you're going to be close knit". This is how she approaches the project, envisioning the neighborly ways the inhabitants will live in this community.

\section{Resident 1: You hope}

Trainee architect: I think that's how personally I approach this project

Resident 1: I's just saying you hope, this is South Kilburn

This enthusiasm is countered by one of the residents who reminds us, "this is South Kilburn". The specific locale of this scheme has a bearing on his expectations. This neighborhood does not daunt the trainee architect as she continues:

Trainee architect: This is exactly what happened in Freiburg and what you now get in Bedford as people are moving in they are actually getting a certain level of support like the garden and everything and whoever moves in, it's like

\section{Resident 4: Infectious}

Trainee architect: Yeah, like people will adapt and will see what other people are doing and no one knows what people will do with the spaces and you kind of pull people along and take them along on that route you know, am I too idealistic? 
This housing project is being framed as transformative, in a similar way to "what happened in Freiburg and in Bedford". The enthusiasm and optimism she shows is qualified as she reflects, "am I too idealistic?"

Housing officer: My experience is that you design for people and basically the spaces shouldn't force people to move into them you should design for people and what happens is that people assume, what you're saying is obviously the ideal, but actually in reality, most times that does not happen

Project architect: Right

In response, the housing officer reminds us that "basically the spaces shouldn't force people to move into them" or define a script for a way of life within them. This mindset is in keeping with Brand's notion that buildings adapt in use and does not mandate that the inhabitants live in particular ways. The housing officer acknowledges that an ideal scenario is being described and that most of the time this does not happen. The project architect who has many years' experience designing these kinds of projects agrees with this sentiment.

In these conversations, it is noticeable that although there is an enthusiasm for this new housing project to engender a greater sense of community on this estate, there is an acknowledgement that the dwellings themselves are only part of this challenge. The transformation is not just technical. The management of the estate and support provided for the residents are entangled in this system and its ability to change. What people do within buildings however does influence its environmental impact and the next section examines how these interactions can be viewed as an opportunity to learn how lifestyle affects energy use in buildings.

\subsection{Living in Similar Dwellings, Consuming Energy in Different Ways}

A housing project where similar dwellings are occupied by different people differently is an opportune setting to compare, emulate and learn from the practices of others. Routinely, even when living in similar dwellings on an estate, residents are unaware of neighbour's energy bills or how differences in lifestyle and occupancy patterns effect the energy each dwelling consumes. In the conversation that follows the mechanical and electrical M\&E engineer designing the building services is "looking for a steer" from the resident group. It is how he describes the energy demand for different households that is illuminating.

M\&E engineer: I'm looking for sort of a few decisions and a steer for what you guys want and how you want the buildings to be before we get on with the design of the first one, I've got some ridiculous looking houses here just to show, we've got a row of five houses there, the top lot, these people have got 10 kilowatts of heat, who knows whether that's enough just a round number so they're got a 10 kilowatt boiler, so they're happy so that meets their needs, this lot here there's only one person in and they've got upstairs all shut off so actually they only need 5 kilowatts but they've still got a 10 kilowatt boiler, these people are out but they've still left the heating on a little bit so they only need 2 kilowatts these people are in but they got the windows shut so they only need 8, but they've got 10 kilowatts of boiler and this lot here are, useless because they've got all the windows open they've got all the hot water going someone's using a shower and they're actually using 12 kilowatts and the poor boiler is belting away cause they've only been given a 10 kilowatt boiler, so the sum total of all 
that is that everyone has got their own individual boiler and what I'm going to be asking is whether that's the sort of thing as a principle, where each unit is totally individual and has its own equipment, or whether we should be looking at a communal set of plant, which then serves the individual unit?

Using hypothetical scenarios, the M\&E engineer, in an amusing way, illustrates that similar dwellings occupied in different ways will have different energy loads. Lessons he delivers through this story are that closing windows, shutting off upstairs are ways of configuring a dwelling so it consumes less energy. Taking a shower at the same time as drawing on other heating load places high demand on a domestic boiler.

The engineer continues,

...so taking this example just one step further, we've got five more ridiculous looking houses and we've got the same people in and they're doing exactly the same thing, these people have still got their windows open, they don't learn (laughter) but instead of each having a 10 kilowatt boiler we've actually put a separate 50 kilowatt boiler which may be somewhere else so this means they're getting their heat at improved efficiency we can save a lot of money on plant we can save space because the plant itself is smaller and not within dwellings I don't know if you want to make comments now or come back to that?

The M\&E engineer, in this tale of five dwellings, suggests that communal heating would be a good solution for this estate. The story includes the moral tale of the house that does not learn, "still got their windows open", which the group finds amusing. In this description, there is no obvious opening to debate this idea, as saving money and space, are all positive reasons to adopt this suggestion. One of the residents, however, does want to comment on this.

Resident 1: I wanted to make a comment, in the past we've had a communal central heating system and we've been told we have a stand by heating system and we've had no heating for say a fortnight perhaps if its $100 \%$ maintained

Knowing just what the residents already know about buildings is an uncertainty in any participatory design situation. In the previous extract, it is the experiential knowledge of one resident that becomes important to his acceptance of the proposal. This resident makes a connection between the district heating he has experienced in the past and the communal heating technologies that are being proposed. This is not an encouraging connection. However, the resident does acknowledge that these technologies may now be more reliable and that the maintenance of the system is important. This resident is able to associate different parts, technologies and practices in a system that connects the operation of a boiler with maintenance cycles and the local authority's support for the estate, to assess whether today's combined heat and power systems will be more reliable than the district heating supply on the estate thirty years ago.

M\&E engineer: Heavy-duty boilers are more robust than domestic scale

In response, the $M \& E$ engineer provides the reassurance that the boilers will be robust and the project architect reinforces this view saying, 
Project architect: One of the points we're trying to talk about is the overall and individual benefits and the differences between the type of plant available now and district heating and the benefits the whole community gets, but boilers are individually controlled within a house

In this brief exchange, it is noted that the resident is not wholly adverse to the idea of communal heating, even after his experience living with a failing heating system. He is, however, looking for reassurance that this experience will not be re-visited in the homes of the future. The project architect then elaborates, describing the individual and overall benefits from communal heating. The energy solution proposed for this estate reinforces a community-ethos and not just individual gain within a dwelling.

The benefits to the local community are emphasized. Although space heating and the regulation of hot water will be individually controlled, in this scenario it is noted that living in these dwellings in comfort is entangled with the management and maintenance regimes for the estate. The building services supplying heating and hot water to a dwelling are understood as part of a larger system serving the housing block, which is in turn contingent on estate maintenance regimes and inputs from other actors. This resident reveals his understanding that the supply of heat to each dwelling, the maintenance of the system and sustained support from the local authority are interdependent in the smooth running of this system. In the next episode it is what a resident does not know that is of interest.

\subsection{Understanding Conventional Domestic Heating}

The houses that most of us inhabit include wall-mounted radiators as part of a central heating system. Precisely how these technologies are embedded in the home and how they run ubiquitously in the background are seldom questioned, until the heating system stops working. However, in these design interactions the heating of the home and the operation of other building services are the main subjects of conversation and we glean important insights into how well these systems are understood and how some occupants conceptualize how a building works. In the next episode, a resident is unsure if "convective heating" is another kind of heating system.

Resident 2: What is convective heating?

Project architect: You can best compare it with the winter when you stand next to a cold window you can feel a draft and you can feel cold

Resident 2: Yeah

Trainee architect: Although you can't actually feel the air move it is actually your body radiating it's heat, giving it away, to the window, and the same thing happens if you have a warm wall and you will feel that warmth so it's meant to be more pleasant, which is like an underfloor heating system.

Project architect: What the Engineer was saying is that most of us are used to having radiators but he's was saying that they're not very well named cause they don't really radiate heat, they warm up the air around them and that air moves and so they're not all that good at doing the heating job

While the occupants may not need or want to know how the central heating system in their home works in detail, from this conversation it is evident that some residents are unsure how conventional heating technologies such as radiators emit heat. With a basic understanding of how the movement of air from the loss of heat from a radiator results in the sensation of warmth the residents and the design 
team were then able to discuss perceptual qualities of heating. These simple concepts then broaden the experiential range with which they can then talk about the design of the heating system for the dwellings.

In these conversations, it can be seen that, on occasion, there is limited understanding of some of the routine technologies in the home. It is not just new low-carbon technologies that are complex but the controls and interfaces for the building systems people come into contact with everyday that are not well understood. In the next episode we gain insight into how the supply of water within the home is conceptualized.

\subsection{Water in Buildings}

Being able to gauge what is already known and understood and what will be a new concept or technology for the residents is part of the architect's art in these encounters. Rainwater harvesting is not a new idea and one of the residents, building on her own experience, suggests a form of harvesting "one of my ideas if you have a kind of a tank, it's a box, you could also recycle the water so you can wash your hair, it's really nice you know". Although rainwater harvesting is not mentioned specifically this is the concept that the resident describes. The architect, encouraged by this level of conceptual understanding, then elaborates on the seriousness of domestic water (mis)use.

Project architect: At the moment in Britain we purify our water and we spend lots of money on that then we flush our toilets with water of that quality, that's drinking quality water and that seems crazy

Amongst the group there is agreement that this practice is "awful", signaling the collective view that using drinking quality water in this way is irrational. This disposition bodes well, as the architect begins to describe different degrees of water recycling that could be used in the scheme.

Project architect: A very low tech version, you can start using them to actually catch the water from the roof and start flushing toilets with it, you can do other things as well like washing machines but sometimes people aren't you know very keen on that, and it's also insurance of the equipment and stuff cause it's quite hard water. Then you can take it further again and the water that you use from for example the showers can again be filtered and pumped back up to flush your toilets, cause toilet use is actually the highest water use in the home, and so there are several levels of what you can do, obviously the higher up you go the lower your bills will be but the higher the cost to install it

In his description there is progression from harvesting rainwater, to filtering and re-cycling grey water within a dwelling, re-iterating that toilets are the "highest water use in the home". Using re-cycled water in washing machines is noted as more complex. There is a trade-off between the installation cost and reduced running costs when selecting different water re-use and cleansing systems, an observation noted by another housing client [32]. As the conversation continues another of the residents reveals their confusion and difficulty in understanding different water uses within a dwelling.

Resident 1: I need to ask about grey water usage, can you clarify this to us please, the grey water usage, the water from the mains to reduce water bills for the residents cause I just wonder is that the water for the under flooring heating?

Project architect: No 
Resident 2: That's water that you've got basically, grey water is like rain water or perhaps water that you've used already

Project architect: From washing and from the kitchen and from the shower

Resident 1: So that's sort of like from yourself?

Project architect: Yeah

Resident1: You're not going to go right through with grey water?

Resident 2: Just for the toilets and the garden

It is evident that this resident understands that water re-cycling will reduce their bills but is unclear where grey water comes from, and how does the water from the underfloor heating system fit into this cycle? One of the other residents and architect begin to clarify. Grey water is not water in the underfloor heating system it is water "you've already used". The realization that it is "from yourself" does not sound appealing and she asks "you're not going right through with the water the grey water?" Again someone from the resident group reassures her it will only be used for toilets and gardens, and as the conversation progresses.

Assistant architect: Grey water actually means used water already in the home that you then filter you don't want it to come out looking bubbly with soap in you know it's got to be filtered, whatever is flushed through gets filtered and gets cleared but just for toilet flushing

Resident 1: Um I'm not really

Assistant architect: Well this is actually all designed in, this is what we're looking at now

Housing officer: We've got to be looking at innovative ways we've got to think of how much water we're using for each toilet flush and how much it's costing to clean it to get to that point when for example you talked about using rain water for washing hair, well that might be good for one person but this is not for personal use it would be just certain types that's correct isn't it?

Assistant architect: Yeah

Resident 2: Certain types of used water are solely for flushing your toilets and it has to go through a process of being cleaned before it can be used in the toilet, it's just that cleaning process is bound to be cheaper and shorter

Resident 3: And lots more, having a quicker turn round cycle isn't it compared to fresh water, you might as well call it that

Resident 2: Yes but there is the installation cost at the beginning

Resident 3: What they're saying there's perhaps a long-term gain but there's a short-term expense

Project architect: That's absolutely true and also you still need to be on your mains, on your

Thames Water

Several residents are keen to clarify just what grey water is and its advantages, quicker and cheaper cleaning process, in an attempt to dispel the reservations of one of the residents. The conversation is informative and pedagogic. It becomes a shared, communal problem to explain to others how the systems within buildings work, acting in spirit of participation advocated by Bookchin. The architects have already designed a water re-cycling system for this scheme and the housing officer supports the inclusion of innovative ways to reduce the cost of cleaning water. Evidently, while keeping the cost of water bills low was a shared, community concern, the prospect of re-using water was not universally well received. 
Within the home perhaps it is the ready availability of clean "fresh" water that masks the reality that all water is re-cycled.

\section{Reflection on Transitions to Lower-Impact Living}

Raising the question, how people learn how to live in dwellings, does play with reductionist notions, knowing that it is because people do not inhabit buildings logically, in scripted ways determined by the technologies they interact with that lowering our impact on the environment continues to be problematic. Low-impact living is not just a technical problem. This was evident in this research examining how people talked about living in dwellings, in their everyday contact with technologies in the home that revealed some assumptions, preferences and (mis)understandings. Ways of living and dwelling as Lave and Ingold [26,33] point up are not planned but are part of the ongoing, changing relations between people and practices in a changing world. People change through their everyday practice. Everyday practices change as the participants change. Building on this understanding of being and learning in the world what was revealed through these episodes are rich, situated insights into how some technologies for this housing estate were understood by the future occupants. In this setting, it was possible to illustrate just how the ideology of low-impact design meets the occupant's lived accounts of life on this estate and their construal of how a house works. These accounts have highlighted a problem that is currently under-acknowledged in the transition to a lower-carbon economy: that people do not know how to use some routine technologies within the home.

\subsection{What Is It That Makes Today's Homes So Different}

One of the challenges that architects face is establishing just what the future residents do not understand about the operation of technologies within their homes. However, are today's homes so technologically complex? Are today's homes so different? These questions make a deliberate connection with Richard Hamilton's 1956 collage “Just what is it that makes today's homes so different, so appealing?" presented at the This is Tomorrow exhibition and also the question posed by Brenda and Robert Vale, "How do modern houses differ from those of the past?" in Design and Technology teaching materials [15], which describe how to design housing that consumes less energy. Evidently we still continue to question how we live in housing and how our habitation will be changed by "new" technology. The technological solutions described by the Vales and those proposed for today's "new" housing are remarkably similar. It is the transition, mainstreaming the uptake, adoption and implementation of lower-impact technologies that continues to be problematic.

What these episodes have shown is just how some of the routine and mundane building services that the residents are in daily contact with were misunderstood. It is not just the building controls characteristically associated with micro-generation that are complex, for instance, to operate a washing machine at peak photovoltaic output. Some of the routine systems within a dwelling caused confusion, for example, knowing that water circulating in an underfloor heating system is independent from water in a toilet system. Sometimes people do not understand the basic operations of heating and water within a house. Seemingly, raising a user's conceptual understanding of how a house works will become even more important as we encourage lower-impact living. 
To help develop this conceptual understanding these architect-user interactions provide an opportunity for the future users of buildings to learn about systems within buildings before they take occupancy. These design interactions help mitigate some of the previously reported misunderstandings and misconceptions, such as thinking that solar water heating panels on a roof generate electricity [9]. These select episodes begin to reveal the learning potential of the interactions between architects and users at the design stage. The interactions serve several purposes. Firstly, these events enable conversations to take place to inform the (re)design of the scheme. At the same time, they provide a forum where the future occupants of a dwelling can question some taken for granted assumptions about technologies within the home and how to use them. Occupants can gain important insight into what the designers think living in these dwellings will be like. They also find out more about their neighbour's habits, including patterns of occupation and heating usage. These can be important reflective conversations, enabling the residents to compare practices and to learn from others living in similar dwellings.

A community ethos is also being engendered through these interactions, in the spirit of Bookchin [17]. These conversations are primarily events that helped raise awareness of how to live on this estate with less impact on the environment, for example, reasoning that a communal combined heat and power unit is better suited to collective practices than individual boilers. Additionally, at these events local social networks are being built. These are planned events that provide a vehicle to discuss life on this estate and the challenges the residents face, with people who may be able to help address them. These encounters do provide a platform where the exchange of opinion, values and ways of working together are being encouraged and their community building value is noticeable.

\subsection{Changing Design Practices}

Studying these episodes, we can identify several characteristics of these events, and draw attention to a form of design practice that it is proposed should occur more often. Importantly, it is because the interaction between architects and inhabitants is direct that this exchange is most valuable. The events are staged sufficiently early, when any changes can still be incorporated within a scheme but when the people who will likely inhabit the dwellings are known. Talking directly to the people who will live in the dwellings is important rather than this exchange being facilitated, interpreted and represented by another party. While the architect as an enabler of change is being encouraged [34] through this research it is possible to be more specific, articulating what this design service might look like as part of the procurement process in the UK. There are already initiatives in America to increase architect's activism, through the public interest design (PID) movement, which acknowledges that there are more problems to solve than architects currently address and new markets for architectural services [35]. It is important in PID, and as was borne out in this research, that architects have direct interaction with user-clients, that these interactions are not facilitated by other people and that the views expressed at these events are not those of representatives. The political motives for these conditions (ethics, power and representation) are well known and also, from organizational studies, that increasing the number of consultants and facilitators will increase the chain of communication to make the negotiation of stakeholder values more complex. Therefore, while there are numerous advances and approaches to social innovation in the area of community intervention, this research is able to identify several advantages of a particular form of participation on projects, through architects' direct interaction with the future occupants of buildings. 
At the moment, however, there is a difference between the design process for this housing project and the production of the majority of the domestic housing stock. A local authority appointed this architectural practice to design this housing scheme. While "in the developed world the great majority of buildings, perhaps $80 \%$ by value, are not designed by architects most of the non-architectural buildings are houses" [36] (p. 8). What is needed then is greater awareness of the value architects meeting with users adds to a project. Public meetings with project architects are mandatory in the design of social housing projects. A recommendation, based on these observations, is that similar architect-user design events be introduced in the procurement process for other building types and particularly for more of the UK housing stock, where lower-impact living in communities is being encouraged.

\section{Conclusions}

People do inhabit housing without knowing how the services within a home were designed to be used. We have seen that it is not just the micro-generation technologies in new-build homes with intricate building controls that are misunderstood. The observations from this study reveal, firstly, that when dwellings are inhabited with a partial understanding of how to use technologies that this lacuna, in part, limits our transition to lower-carbon living. To begin to redress this, "learning how to use buildings" is a pragmatic and critically reflective question and also poses a design paradox, as buildings are not used in a determinate manner. The settings where we might learn more about how buildings work, and the systems and technologies within buildings therefore become important.

The design events that were staged by the architects were meaningful for several reasons. Not only for architects to better understand more about particular user preferences but also for the users to learn more about the technologies that are being embedded within the dwellings they will inhabit. These interactions between architects and users can be considered pedagogic in several ways, knowing more about what the dwellings will be like and what other people think about services and technologies within the home. It was because the architects meet and talk to the users in person that this exchange was valuable and also because it took place at a stage when talking and reasoning through the consequences of individual actions and practices at the community scale can still influence what is designed.

The potential of these events to transform, to engender a stronger sense of community, is currently under-acknowledged. The events were seen to engender a community-minded ethos and are already written into the design process for some housing projects. The events begin to encourage group reflection on the impact of estate living, raise awareness of energy consumption patterns and play a part in the social relational knotwork that underpins the formation of communities. For the transformational benefits of these events to impact at scale, a larger percentage of the UK housing stock and not just exceptional social housing projects, need to appoint architectural practices to stage similar design events.

\section{Acknowledgments}

This research would not have been possible without the residents', architects' and housing officers' informed consent to shadow this project, to see how the design of this housing estate project took shape. The constructive comments of the editors and two anonymous reviewers are also acknowledged. 


\section{Conflicts of Interest}

The author declares no conflict of interest.

\section{References}

1. Brand, S. How Buildings Learn: What Happens after They Are Built; Viking Penguin: London, UK, 1994.

2. Bijker, W.E.; Hughes, T.P.; Pinch, T. The Social Construction of Technological Systems: New Directions in the Sociology and History of Technology; Massachusetts Institute of Technology (MIT) Press: Cambridge, MA, USA, 1986.

3. Geiryn, T.F. What buildings do? Theory Soc. 2002, 31, 35-74.

4. Groák, S. The Idea of Building: Thought and Action in the Design and Production of Building; E\&FN Spon: London, UK, 1992.

5. Sunikka-Blank, M.; Galvin, R. Introducing the prebound effect: The gap between performance and actual energy consumption. Build. Res. Inform. 2012, 40, 260-273.

6. Boardass, B.; Leaman, A.; Bunn, R. Controls for End Users: A Guide for Good Design and Implementation; Building Services Research and Information Association (BSRIA): Bracknell, UK, 2007.

7. National House Building Confederation Foundation (NHBC). How Occupants Behave and Interact with Their Homes: The Impact on Energy Use, Comfort, Control and Satisfaction; Building Research Establishment (IHS BRE) Press: Milton Keynes, UK, 2011.

8. Roy, R.; Caird, S. Diffusion, user experiences and performance of UK domestic heat pumps. Energy Sci. Technol. 2013, 6, 14-23.

9. Goodchild, B.; O'Flaherty, F.; Ambrose, A. Inside the eco-home: Using video to understand the implications of innovative housing. Hous. Theory Soc. 2014, 31, 334-352.

10. Vale, B.; Vale, R. Domestic energy use, lifestyles and POE: Past lessons for current problems. Build. Res. Inform. 2010, 38, 578-588.

11. Brand, S. The Whole Earth Catalog; Quantum Press: Oakland, CA, USA, 1968.

12. Hunt, S. The Revolutionary Urbanism of Street Farm: Eco-Anarchism, Architecture and Alternative Technology in 1970s; Tangent Books: Bath, UK, 2014.

13. Rodden, T.; Crabtree, A.; Hemmings, T.; Koleva, B.; Humble, J.; Åkesson, K.P.; Hansson, P. Between the Dazzle of a New Home and Its Eventual Corpose: Assembling the Ubiquitous Home. In DIS; Association for Computing Machinery Press: New York, NY, USA, 2004; pp. 71-80.

14. Pink, S. Situating Everyday Life; Sage Publications Ltd.: London, UK, 2012.

15. Vale, B.; Vale, R. Design Processes and Products: Houses Analysis and Synthesis; The Open Unviersity Press: Milton Keynes, UK, 1982.

16. Georg, S. The social shaping of household consumption. Ecol. Econ. 1999, 28, 455-466.

17. Bookchin, M. The Ecology of Freedom; Cheshire Books: Palo Alto, CA. USA, 1982.

18. Zero Carbon Britain: Rethinking the Future; Centre for Alternative Technology: Machynlleth, UK, 2013. 
19. Van Rossem, W. Climax Solar-Water Heater. In Co-Evolution Quarterly, Fall 1977; The Whole Earth Catalog: Austin, TX, USA, 1977.

20. Gehl, J. Cities for People; Island Press: Washington, DC, USA, 2010.

21. Holden, M. Social learning in planning: Seattle's sustainable development codebooks. Prog. Plan. 2008, 69, 1-40.

22. Seyfang, G.; Haxeltine, A. Growing grassroots innovations: Exploring the role of community-based initiatives in governing sustainable energy transitions. Environ. Plan. C 2012, 30, 381-400.

23. Foxon, T. A co-evolutionary framework for analysing a transition to a sustainable low carbon economy. Ecol. Econ. 2011, 70, 2258-2267.

24. Gupta, R.; Barnfield, L.; Hipwood, T. Impacts of community-led energy retrofitting of owner-occupied dwellings. Build. Res. Inform. 2014, 42, 446-461.

25. Noonan, D.; Chiang-Hsieh, L.H.; Matisoff, D. Spatial effects in energy-efficient residential HVAC technology adoption. Environ. Behav. 2011, 45, 476-503.

26. Lave, J. Apprenticeship in Critical Ethnographic Practice; The University of Chicago Press: London, UK, 2011.

27. Ingold, T. The Perception of the Environment: Essays on Livelihood, Dwelling and Skill; Routledge: London, UK, 2000.

28. Heidegger, M. Being and Time; Harper: New York, NY, USA, 1962.

29. Holden, M. The tough minded and the tender minded: A pragmatic turn for sustainable development planning and policy. Plan. Theory Pract. 2008, 9, 475-496.

30. Orr, D. The Nature of Design: Ecology, Culture and Human Intention; Oxford University Press: Oxford, UK, 2002.

31. Luck, R. Learning to talk to users in participatory design situations. Des. Stud. 2007, 28, 217-242.

32. Bennie, C.; Wainwright, E. Designing development. Archit. Res. Q. 2014, 18, 92-96.

33. Ingold, T. Being Alive: Essays on Movement, Knowledge and Description; Routledge: London, UK, 2011.

34. López-Piñeiro, S. Reconsidering the enabling architect. Archit. Res. Q. 2010, 14, 286-288.

35. Bell, B.; Wakeford, K. Expanding Architecture: Design as Activism; Metropolis Books: Los Angeles, CA, USA, 2008.

36. Davies, C. The Prefabricated Home; Reaktion Books: London, UK, 2005.

(C) 2014 by the authors; licensee MDPI, Basel, Switzerland. This article is an open access article distributed under the terms and conditions of the Creative Commons Attribution license (http://creativecommons.org/licenses/by/4.0/). 